\title{
Determination of Minimum Inhibitory Concentration (MIC) and percentage Bacterial Growth Inhibition of essential oils against Gram Positive Bacterial pathogens
}

\author{
S. Nagalakshmi' ${ }^{1}$ P. Saranraj ${ }^{2 *}$ and P. Sivasakthivelan ${ }^{3}$ \\ 1Department of Biochemistry, Sacred Heart College (Autonomous), Tirupattur, Vellore district, Tamil Nadu, India. \\ 2Department of Microbiology, Sacred Heart College (Autonomous), Tirupattur, Vellore district, Tamil Nadu, India. \\ ${ }^{3}$ Department of Agricultural Microbiology, Faculty of Agriculture, Annamalai University, Annamalai Nagar, Chidambaram, Tamil Na du, India.
}

\begin{abstract}
Essential oils and volatile constituents extracted from Aromatic plants are frequently used in folk medicine for prevention and treatment of different human diseases. The urge to develop alternative treatment strategies follows three different directions. In the present study, an attempt has been planned to determine the Minimum Inhibitory Concentration (MIC) and Percentage Growth Inhibition of Essential oils against two Gram positive bacterial pathogens, Staphylococcus aureus and Bacillus subtilis. The Essential oils selected for the present study was collected from Sidha Medicine Shop, Tirupattur, Vellore district, Tamil Nadu, India. The Broth dilution method was used for the determination of Minimum Inhibitory Concentration (MIC) of Essential oils. The Minimum Inhibitory Concentration (MIC) studies were conducted by using various concentrations of Essential oils viz., $25 \mu \mathrm{l} / \mathrm{ml}, 50 \mu \mathrm{l} / \mathrm{ml}, 75 \mu \mathrm{l} / \mathrm{ml}$ and $100 \mu / \mathrm{ml}$. The Essential oils exhibits inhibitory activity against Gram positive bacteria in all the concentrations. Among the seven Essential oils tested, Mahualongif oil has showed maximum percentage bacterial growth inhibition when compared to other Essential oils. The inhibitory activity of Mahualongif oil was observed more in Staphylococcus aureus when compared to Bacillus subtilis. For Staphylococcus aureus, lowest inhibitory percentage was noticed in Pungam oil and for Bacillus subtilis lowest inhibitory percentage was noticed in Coconut oil.
\end{abstract}

Keywords: Essential oils, Minimum inhibitory concentration (MIC), Percentage bacterial growth inhibition, Bacillus subtilis and Staphylococcus aureus.

Article Info: Received 15 March 2019; $\quad$ Review Completed 20 April 2019; $\quad$ Accepted 22 April 2019; Available online 15 May 2019

Cite this article as:

Nagalakshmi S, Saranraj P, Sivasakthivelan P, Determination of Minimum Inhibitory Concentration (MIC) and percentage Bacterial Growth Inhibition of essential oils against Gram Positive Bacterial pathogens Journal of Drug Delivery and Therapeutics. 2019; 9(3):33-35 http://dx.doi.org/10.22270/jddt.v9i3.2596

물 * Address for Correspondence:

P. Saranraj, Department of Microbiology, Sacred Heart College (Autonomous), Tirupattur, Vellore district, Tamil Nadu, India.

\section{INTRODUCTION}

A large portion of the world population, especially in developing countries depends upon the traditional system of medicine for treating variety of infectious diseases. Several hundred genera of plants are used as vital sources for potent and powerful drugs ${ }^{1}$. In herbal medicine, crude plant extracts in the form of herbal extracts are used by the population for the treatment of diseases, including infectious diseases. Although, their efficacy and mechanism of action have not been tested scientifically in most cases, these simple medicinal preparations often mediate beneficial responses due to their active chemical constituents ${ }^{2}$.

Essential oils are volatile, natural, complex compounds that are produced by plants as secondary metabolites for protection against bacteria, viruses, fungi and pests ${ }^{3}$. They also have an important role in dispersion of pollens and seeds by attracting some insects. In Middle Ages, essential oils were used for preservation of foods and as flavoring, antimicrobial, analgesic, sedative, antiinflammatory, spasmolytic and locally anesthetic remedies. But, characterizing these properties in laboratory dated back to the early 1900s. At present, about 3000 essential oils are known and 300 of them are used commercially in different industries such as pharmaceutical, agronomic, food, sanitary, cosmetic and perfume 4 . Today, antioxidant, antitumor and antiviral, antifungal and antibacterial activity of essential oils and their constituents is widely studied by various researchers ${ }^{5}$.

Essential oils are made from a very complex mixture of volatile molecules that are produced by the secondary metabolism of aromatic and medicinal plants and can be obtained by different methods, including the use of low or 
high pressure distillation of different parts of plants or the employment of liquid carbon dioxide or microwaves. Several factors influence the quality and quantity of the extracted product, in particular the soil composition, plant organ, vegetative cycle phase and climate 6,7 .

The essential oils are complex mixers comprising of many single compounds. Chemically they are derived from Terpenes and Terpenoids (Isoprenoids) and aromatic and aliphatic aldehydes and phenols, all characterized by low molecular weight ${ }^{8}$. Each of these constituents contributes to the beneficial or adverse effects. There are many methods of extraction of essential oils. They can be obtained by steam distillation, mechanical expression, hydro distillation, fermentation or extraction but the method of Steam distillation is most commonly used for commercial production. During distillation, water condensate and is separated by gravity leaving a very small amount of volatile liquid that is the essential oil. Due to their extraction procedure, they contain a variety of volatile molecules such as Terpenoids, Terpenes, Aromatic compounds and aliphatic components 9 . The present study has been planned to determine the Minimum Inhibitory Concentration (MIC) and Percentage Growth Inhibition of Essential oils against two Gram positive bacterial pathogens, Staphylococcus aureus and Bacillus subtilis.

\section{MATERIAL AND METHODS}

\section{Essential oils selected for present research}

a) Pungam oil - Pongamia pinnata

b) Mahualongif oil - Madhuca longifolia

c) Sesame oil-Sesamum indicum

d) Castor oil - Ricinus communis

e) Groundnut oil-Arachis hypogaea

f) Neem oil - Azadirachta indica

g) Coconut oil - Cocos nucifera

\section{Collection of Essential oils}

The Essential oils selected for the present study was collected from Sidha Medicine Shop, Tirupattur, Vellore district, Tamil Nadu, India.

\section{Collection of test Bacterial cultures}

Two different Gram positive bacterial cultures, Staphylococcus aureus (Gram positive cocci) and Bacillus cereus (Gram positive bacilli) were procured from Microbial Type Culture Collection (MTCC), Chandigarh, India.

\section{Maintenance of bacterial cultures}

The bacterial cultures were sub-cultured and maintained on Nutrient agar slants and stored in refrigerator at $4{ }^{\circ} \mathrm{C}$.

\section{Bacterial inoculum preparation}

Bacterial inoculum was prepared by inoculating a loopful of bacteria in $5 \mathrm{ml}$ of Nutrient broth and incubated at $37^{\circ} \mathrm{C}$ for 12 hours till a moderate turbidity was developed. The turbidity was matched with 0.5 McFarland standard and then used for the determination of antibacterial activity.

\section{Determination of Minimum Inhibitory Concentration (MIC) Broth Dilution Method}

The Broth dilution method proposed by Ericsson and Sherris 10 was used for the determination of Minimum Inhibitory Concentration (MIC) of Essential oils against two selected Gram positive bacteria, Staphylococcus aureus and Bacillus subtilis. Essential oils were diluted into various concentrations viz., $25 \mu \mathrm{g} / \mathrm{ml}, 50 \mu \mathrm{g} / \mathrm{ml}, 75 \mu \mathrm{g} / \mathrm{ml}$ and 100 $\mu \mathrm{g} / \mathrm{ml}$ in a sterile Nutrient broth in test tubes. Using standard wire loop (Hi-media), a loopful of Gram positive bacterial culture was inoculated into test tubes containing various concentrations of Essential oils in Nutrient broth. The tubes were incubated at $37{ }^{\circ} \mathrm{C}$ for 24 hours and thereafter observed for growth or turbidity. The bacterial growth which was observed in the form of turbidity was measured by using UV Visible Spectrophotometer (SYSTRONICS - 108) at $600 \mathrm{~nm}$ and the Optical density was recorded. These experiments were repeated three times.

\section{Determination of Percentage growth inhibition}

The Percentage bacterial growth inhibition of bacteria was determined by using the formula:

\% Growth Inhibition = Optical Density of Initial Bacterial growth (Nutrient broth inoculated with bacteria) - Optical Density of Inhibited Bacterial growth (after addition of Essential oils)/Optical Density of Initial Bacterial growth $\times$ 100

\section{RESULTS AND DISCUSSION}

The effect of Essential oils on Percentage bacterial growth inhibition was studied in the present research against the Gram positive endospore forming bacilli (rod) Bacillus cereus and results were showed in Table -1 . The Minimum Inhibitory Concentration (MIC) studies were conducted by using various concentrations of Essential oils viz., $25 \mu \mathrm{l} / \mathrm{ml}$, $50 \mu \mathrm{l} / \mathrm{ml}, 75 \mu \mathrm{l} / \mathrm{ml}$ and $100 \mu / \mathrm{ml}$. It was showed that the growth inhibition was observed in all the concentrations and the increase in concentration of essential oils increase the percentage growth inhibition of Bacillus cereus. Among the oils tested, maximum growth inhibition percentage was observed in Mahualongif oil (53.4\%) followed by Groundnut oil (40 \%), Pungam oil (34.4\%), Neem oil (28.4\%), Sesame oil (28\%), Castor oil (23.6\%). Lowest activity was observed against Coconut oil (22.5\%). The Sesame oil alone does not showed any inhibitory activity at $25 \mu \mathrm{l} / \mathrm{ml}$ concentration but it shows inhibitory activity against other concentrations like $25 \mu \mathrm{l} / \mathrm{ml}, 50 \mu \mathrm{l} / \mathrm{ml}, 75 \mu \mathrm{l} / \mathrm{ml}$ and $100 \mu / \mathrm{ml}$.

The effect of Essential oils on Percentage bacterial growth inhibition was studied in the present research against the Gram positive cocci Staphylococcus aureus and findings were tabulated in Table - 2. Various concentrations of Essential oils viz., $25 \mu \mathrm{l} / \mathrm{ml}, 50 \mu \mathrm{l} / \mathrm{ml}, 75 \mu \mathrm{l} / \mathrm{ml}$ and $100 \mu / \mathrm{ml}$ were used to study the Minimum inhibitory concentration (MIC). It was observed that the bacterial growth inhibition was recorded in all the concentrations of Essential oils and the increase in concentration of Essential oils have the capacity to increase the percentage growth inhibition of Staphylococcus aureus. Among the Essential oils tested, maximum bacterial growth inhibition percentage was observed in Mahualongif oil (56.5 \%) followed by Neem oil (30\%), Castor oil (29.6\%), Sesame oil (28.5\%), Ground oil (23.7\%) and Coconut oil (23.6\%). Lowest bacterial growth inhibition percentage was recorded as $23.3 \%$ in the Pungam oil.

Lezcano et al. 11 analyzed the antimicrobial effect of the Sunflower oil against the Gram positive bacterial isolates and showed the inhibitory activity against all the test strains with Minimum Inhibitory Concentration (MIC) which was ranging from 10 to $180 \mu \mathrm{l} / \mathrm{ml}$. The bioactive compound namely Oleozon which was present in the Sunflower oil was more susceptible to Mycobacterium sp. than other bacterial isolates. The result of our present study was in correlation 
with the findings of Lezcano et al. [11] by inhibiting the growth of Gram positive bacterial isolates.

Like our present research, recently Singh ${ }^{12}$ has screened the Essential oils against two Gram positive bacteria Bacillus subtilis and Staphylococcus aureus at four different concentrations viz., 1:1, 1:5, 1:10 and 1:20. The MIC of the active essential oils were tested at concentrations ranging from 0.2 to $25 \mathrm{mg} / \mathrm{m}$. Out of 21 essential oils tested, 19 oils showed antibacterial activity against both Staphylococcus aureus and Bacillus subtilis. In our present study, we determined the Minimum Inhibitory Concentration (MIC) and Percentage bacterial growth inhibition of seven different Essential oils and we found that all the tested oils has showed inhibitory activity against the Staphylococcus aureus and Bacillus subtilis.

Table 1: Minimum Inhibitory Concentration (MIC) and Percentage bacterial growth inhibition of Essential oils against Bacillus cereus

\begin{tabular}{|c|l|c|c|c|c|}
\hline \multirow{2}{*}{ S. No } & \multirow{2}{*}{ Essential oils } & \multicolumn{4}{|c|}{ Percentage bacterial growth inhibition (\%) } \\
\cline { 3 - 5 } & & $\mathbf{2 5} \boldsymbol{\mu l} \mathbf{m} \mathbf{l}$ & $\mathbf{5 0} \mathbf{\mu l} / \mathbf{m l}$ & $\mathbf{7 5} \boldsymbol{\mathbf { l }} / \mathbf{m l}$ & $\mathbf{1 0 0} \mathbf{\mu l} / \mathbf{m l}$ \\
\hline 1. & Pungam oil & $8.62 \%$ & $18.7 \%$ & $25.8 \%$ & $34.4 \%$ \\
\hline 2. & Mahualongif oil & $5.55 \%$ & $13.7 \%$ & $30.2 \%$ & $53.4 \%$ \\
\hline 3. & Sesame oil & $0 \%$ & $12.5 \%$ & $25.0 \%$ & $28.0 \%$ \\
\hline 4. & Castor oil & $9.6 \%$ & $10.5 \%$ & $10.7 \%$ & $23.6 \%$ \\
\hline 5. & Groundnut oil & $6.38 \%$ & $16.0 \%$ & $24.0 \%$ & $40.0 \%$ \\
\hline 6. & Neem oil & $6.56 \%$ & $19.5 \%$ & $21.7 \%$ & $28.4 \%$ \\
\hline 7. & Coconut oil & $5.65 \%$ & $12.5 \%$ & $15.5 \%$ & $22.5 \%$ \\
\hline
\end{tabular}

Table 2: Minimum Inhibitory Concentration (MIC) and Percentage bacterial growth inhibition of Essential oils against Staphylococcus aureus

\begin{tabular}{|c|l|c|c|c|c|}
\hline \multirow{2}{*}{ S. No } & \multirow{2}{*}{ Essential oils } & \multicolumn{4}{|c|}{ Percentage bacterial growth inhibition (\%) } \\
\cline { 3 - 6 } & & $\mathbf{2 5} \boldsymbol{\mu l} / \mathbf{m l}$ & $\mathbf{5 0} \boldsymbol{\mu l} / \mathbf{m l}$ & $\mathbf{7 5} \boldsymbol{\mu l} / \mathbf{m l}$ & $\mathbf{1 0 0} \boldsymbol{\mu l} / \mathbf{m l}$ \\
\hline 1. & Pungam oil & $8.3 \%$ & $12.4 \%$ & $13.3 \%$ & $23.3 \%$ \\
\hline 2. & Mahualongif oil & $4.3 \%$ & $15.2 \%$ & $16.2 \%$ & $56.5 \%$ \\
\hline 3. & Sesame oil & $6.8 \%$ & $24.5 \%$ & $25.1 \%$ & $28.5 \%$ \\
\hline 4. & Castor oil & $10.6 \%$ & $19.1 \%$ & $23.0 \%$ & $29.6 \%$ \\
\hline 5. & Groundnut oil & $6.0 \%$ & $16.0 \%$ & $16.7 \%$ & $23.7 \%$ \\
\hline 6. & Neem oil & $11.1 \%$ & $14.8 \%$ & $25.9 \%$ & $30.7 \%$ \\
\hline 7. & Coconut oil & $6.66 \%$ & $8.66 \%$ & $15.5 \%$ & $23.7 \%$ \\
\hline
\end{tabular}

\section{CONCLUSION}

From the present research, it was concluded that the Essential oils have the capacity to inhibit the growth of Gram positive bacteria in all the concentrations viz., $25 \mu \mathrm{l} / \mathrm{ml}, 50$ $\mu \mathrm{l} / \mathrm{ml}, 75 \mu \mathrm{l} / \mathrm{ml}$ and $100 \mu / \mathrm{ml}$. Among the seven Essential oils tested, Mahualongif oil has showed maximum percentage bacterial growth inhibition when compared to other Essential oils. The inhibitory activity of Mahualongif oil was observed more in Staphylococcus aureus when compared to Bacillus subtilis. For Staphylococcus aureus, lowest inhibitory percentage was noticed in Pungam oil and for Bacillus subtilis lowest inhibitory percentage was noticed in Coconut oil.

\section{REFERENCES}

1) Barnes, J., Anderson, J and Phillipson, J. D. Herbal Medicines, $3^{\text {rd }}$ Pharmaceutical Press, London, 2007; 63(1):23 - 26.

2) Sekhri, K. Antimicrobial Resistance Understanding Solutions and Future Development. International Journal of Pharmaceutical and Biological Science, 2013; 4(2):338-343.

3) Rota, M. C., Herrera, A., Martinez, R. M., Sotomayor, J. A and Jordan, M. J. Antimicrobial activity and chemical composition of Thymus vulgaris, Thymus zygis and Thymus hyemalis. Food Control, 2008; 19:681 - 687.

4) Bakkali, F., Averbeck, S., Averbeck, D and Idaomar, M. Biological Effects of Essential oils - A Review. Food Chemistry and Toxicology, 2008; 46:446 - 475.
5) Vukovic, N., Milosevic, T., Sukdolak, $\mathrm{S}$ and Solujic, S. Antimicrobial activities of Essential oil and Methanol extract of Teucrium montanum. Complementary and Alternative Medicine, 2007; 4:17 - 20.

6) Miguel, M. G., Duarte, J., Figueiredo, A. C., Barroso, J. G and Pedro, L. G. Thymus carnosus Boiss. - Effect of harvesting period, collection site and type of plant material on essential oil composition. Journal of Essential Oil Research, 2005; 17(4):422 426.

7) Angioni, A., Barra, A., Coroneo, V., Dessi, S. and Cabras, P., Chemical composition, seasonal variability, and antifungal activity of Lavandula stoechas L. ssp. Stoechas essential oils from stem/leaves and flowers. Journal of Agriculture Food Chemistry, 2006; 54(12):4364-4370.

8) Freires, I. A., Denny, C., Benso, B., Alencar, S. M and Rosalen, P. Antibacterial activity of essential oils and their isolated constituents against carcinogenic bacteria: A Systematic Review. Molecules, 2015; 20:7329 - 7358.

9) Yap, P. S. X., Yiap, B. C., Ping, H. C. and Lim, S. H. E. Essential oils A new horizon in combating bacterial antibiotic resistance. The Open Microbiology Journal, 2014; 8:6 - 14.

10) Ericsson, H. M. and J.C. Sherris. 1971. Antibiotic sensitivity testing. Report of an International Collaborative Study. Acta. path. Microbiol. Scand., Sec. B, Suppl. No.217.

11) Lezcano, N., Nunez, M., Espim, I., Dupre, A., Pinna, P., Molicotti, G., Fadda and Zanetti, S. (2018). Department of Science Biomedich Degli University Study, Sassari Italy.

12) Singh, N. Impact of Current Transplantation Practices on the Changing Epidemiology of Infections in Transplant Recipients. Lancet Infectious Diseases, 2019; 3:156-161. 